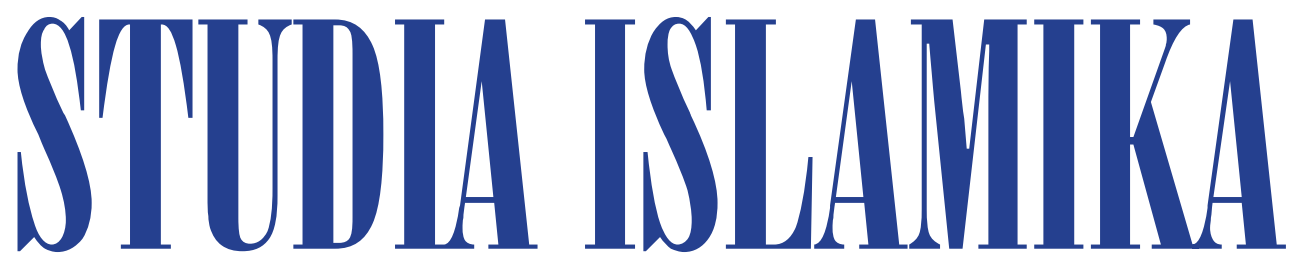

INDONESIAN JOURNAL FOR ISLAMIC STUDIES

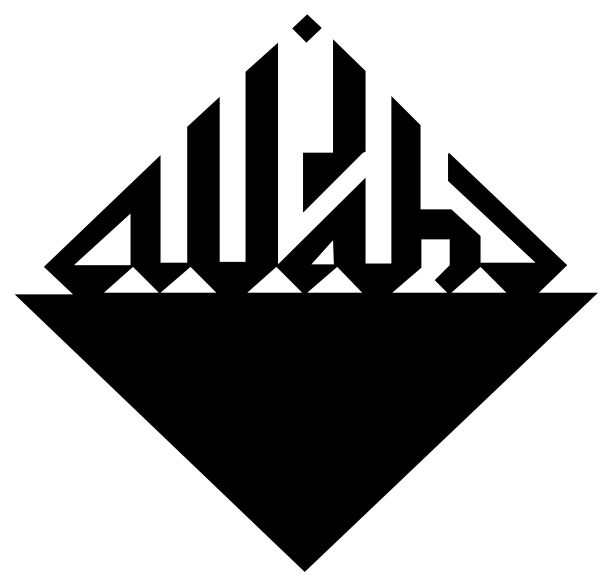

Ritual, BiD'́Ah, ANd the Negotiation of the Public Sphere in Contemporary Indonesia Jajang Jahroni

Historicizing Islam: On the Agency of

Siti Maryam in the Construction of

Bima's HisTORY OF ISLAMIZATION

Muhammad Adlin Sila

Cross-cultural Differences Experienced

during Haju: A Case Study of Acehnese Hajj

Kamaruzzaman Bustamam-Ahmad \& Rahmi Zakaria

Zakat and Poverty Alleviation in a Secular State:

The Case of Muslim Minorities in the Philippines

Alizaman D. Gamon \& Mariam Saidona Tagoranao 
STIUDLA ISLAMIIIKA 



\section{STIDIIA ISLAMIIKK}

Indonesian Journal for Islamic Studies

Vol. 25, no. 1, 2018

EDITOR-IN-CHIEF

Azyumardi Azra

MANAGING EDITOR

Oman Fathurahman

\section{EDITORS}

Saiful Mujani

Jamhari

Didin Syafruddin

Jajat Burhanudin

Fuad Jabali

Ali Munhanif

Saiful Umam

Ismatu Ropi

Dadi Darmadi

Jajang Jahroni

Din Wahid

Euis Nurlaelawati

INTERNATIONAL EDITORIAL BOARD

M. Quraish Shihab (Syarif Hidayatullah State Islamic University of Jakarta, INDONESIA)

Taufik Abdullah (Indonesian Institute of Sciences (LIPI), INDONESIA)

M.C. Ricklefs (Australian National University, AUSTRALIA)

Martin van Bruinessen (Utrecht University, NETHERLANDS)

John R. Bowen (Washington University, USA)

M. Kamal Hasan (International Islamic University, MALAYSIA)

Virginia M. Hooker (Australian National University, AUSTRALIA)

Edwin P. Wieringa (Universität zu Köln, GERMANY)

Robert W. Hefner (Boston University, USA)

Rémy Madinier (Centre national de la recherche scientifique (CNRS), FRANCE)

R. Michael Feener (National University of Singapore, SINGAPORE)

Michael F. Laffan (Princeton University, USA)

\section{ASSISTANT TO THE EDITORS}

Testriono

Muhammad Nida' Fadlan

Endi Aulia Garadian

ENGLISH LANGUAGE ADVISOR

Benjamin J. Freeman

Daniel Peterson

Batool Moussa

ARABIC LANGUAGE ADVISOR

Ahmadi Usman

COVER DESIGNER

S. Prinka 
STUDIA ISLAMIKA (ISSN 0215-0492; E-ISSN: 2355-6145) is an international journal published by the Center for the Study of Islam and Society (PPIM) Syarif Hidayatullah State Islamic University of Jakarta, INDONESIA. It specializes in Indonesian Islamic studies in particular, and Southeast Asian Islamic studies in general, and is intended to communicate original researches and current issues on the subject. This journal warmly welcomes contributions from scholars of related disciplines. All submitted papers are subject to double-blind review process.

STUDIA ISLAMIKA has been accredited by The Ministry of Education and Culture, Republic of Indonesia as an academic journal (SK Dirjen Dikti No. 56/DIKTI/Kep/2012).

STUDIA ISLAMIKA has become a CrossRef Member since year 2014. Therefore, all articles published by STUDIA ISLAMIKA will have unique Digital Object Identifier (DOI) number.

STUDIA ISLAMIKA is indexed in Scopus since 30 May 2015.

Editorial Office:

STUDIA ISLAMIKA, Gedung Pusat Pengkajian

Islam dan Masyarakat (PPIM) UIN Jakarta,

Jl. Kertamukti No. 5, Pisangan Barat, Cirendeu,

Ciputat 15419, Jakarta, Indonesia.

Phone: (62-21) 7423543, 7499272, Fax: (62-21) 7408633;

E-mail: studia.islamika@uinjkt.ac.id

Website: http://journal.uinjkt.ac.id/index.php/studia-islamika

Annual subscription rates from outside Indonesia, institution: US\$ 75,00 and the cost of a single copy is US\$25,00; individual: US\$ 50,00 and the cost of a single copy is US\$ 20,00. Rates do not include international postage and handling.

Please make all payment through bank transfer to: PPIM, Bank Mandiri KCP Tangerang Graha Karnos, Indonesia, account No. 101-00-0514550-1 (USD),

Swift Code: bmriidja

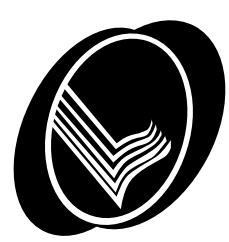

Harga berlangganan di Indonesia untuk satu tahun, lembaga: Rp. 150.000,-, harga satu edisi Rp. 50.000,-; individu: Rp. 100.000,-, harga satu edisi Rp. 40.000,-. Harga belum termasuk ongkos kirim.

Pembayaran melalui PPIM, Bank Mandiri KCP Tangerang Graha Karnos, No. Rek: 128-00-0105080-3 


\section{Table of Contents}

\section{Articles}

$1 \quad$ Jajang Jahroni

Ritual, Bid'ah, and the Negotiation of

the Public Sphere in Contemporary Indonesia

$37 \quad$ Muhammad Adlin Sila

Historicizing Islam: On the Agency of

Siti Maryam in the Construction of

Bima's History of Islamization

67 Kamaruzzaman Bustamam-Ahmad \& Rahmi Zakaria

Cross-cultural Differences Experienced

during Hajj: A Case Study of Acehnese Hajj

97 Alizaman D. Gamon \& Mariam Saidona Tagoranao

Zakat and Poverty Alleviation in a Secular State:

The Case of Muslim Minorities in the Philippines

135 Hermansyah

Khalfiyat wa taḥaddīyāt al-aqalīyah

al-muslimah al-Ṣinīyah fi Pontianak 


\section{Book Review}

177 Dadi Darmadi

Rindu Kembali Ke Baitullah:

Sejarah Haji Asia Tenggara

\section{Document}

199 Dita Kirana

Enhancing Religious Education: An Attempt

to Counter Violent Extremism in Indonesia 
Jajang Jahroni

\title{
Ritual, Bid'ah, and the Negotiation of the Public Sphere in Contemporary Indonesia
}

\begin{abstract}
The politicisation of ritual has been common in Indonesia over centuries. In the 18th century, the Padri people in West Sumatra introduced a puritan Islam creating a long-standing conflict between the Padris and the local Muslim groups in the region. In the early 20th century, the modernists criticized the religious practices of the traditionalist Muslims. In the 1980s, a new group of Salafi people bring back the issues of bid'ah into the Islamic discourses of Indonesian Islam. Adhering to literal interpretations of Islamic teachings, Salafi groups question the validity of rituals associated with traditionalist Muslims, thereby exerting their power over Muslim believers. In response, traditionalists defend their opinions by expanding the definition of bid'ah. Mosques, one of the most strategic institutions in Islam, have provided sites of contestation between traditionalists and Salafis. This has resulted in the politicisation of mosques over the last decades. Having different understandings of rituals, traditionalists and Salafis have used different methods to facilitate social engagement and organizational capacity.
\end{abstract}

Keywords: Ritual, Bid'ah, Public, Negotiation, Social Engagement. 
Abstrak: Politisasi ritual telah terjadi selama berabad-abad di Indonesia. Pada abad ke-18, kaum Padri di Sumatra Barat menyebarkan Islam puritan yang mengakibatkan konflik berkepanjangan di wilayah tersebut. Pada awal abad ke-20, kelompok modernis mengkritik praktik keagamaan kelompok tradisionalis. Pada dekade 1980-an, hal ini terjadi kembali. Kelompok Salafi mempertanyakan keabsahan sejumlah ritual yang dilakukan kelompok traditionalis untuk memperluas pengaruh mereka atas kelompok Muslim lainnya. Sebaliknya, kelompok tradisionalis mempertahankan pendapat mereka dengan memperluas pengertian bid'ah. Kelompok tradisionalis dan Salafi memperebutkan masjid sebagai institusi yang paling strategis dalam Islam. Ini mengakibatkan politisasi masjid dalam beberapa dekade terakhir. Memiliki pemahaman yang berbeda tentang ritual, kelompok tradisionalis dan Salafi mengembangkan metode yang berbeda untuk kehidupan sosial dan pengembangan organisasi.

Kata kunci: Ritual, Bid'ah, Publik, Negosiasi, Pergaulan Sosial.

ملخص: حدث تسييس الطقوس منذ قرون في إندونيسيا. ففي القرن الثامن عشر،

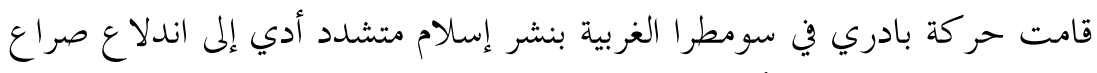

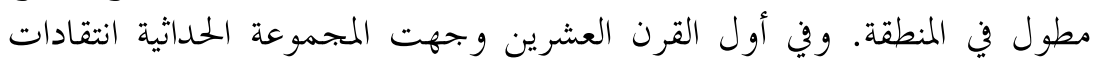

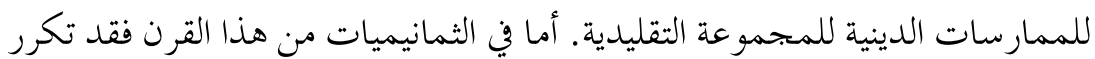
الأمر مرة أخرى، حيث شككت الجماعة السلفية في صحة جملة من الطقوس التي

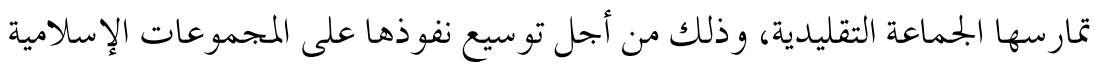

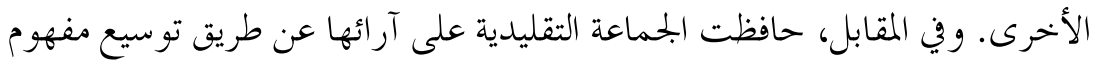

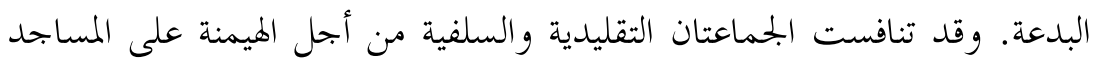

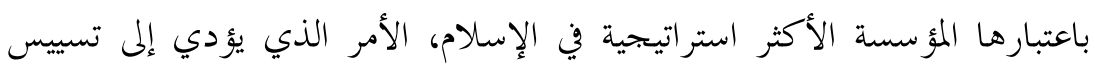

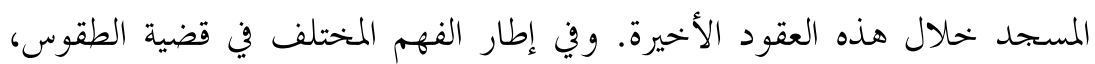

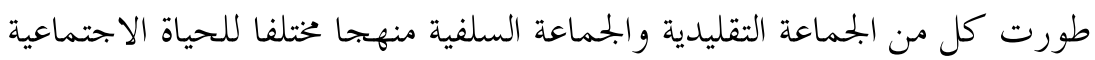
والتطوير التنظيمي.

الكلمات المفتاحية: الطقوس، البدعة، الجمهور، المفاوضة، التفاعل الاجتماعي. 


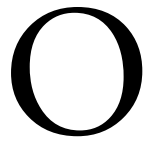
ver the last two decades, the word bid'ah, a belief or a practice for which there is no precedent in the time of the Prophet, loosely translated into English as 'innovation', has made a return in Indonesian religious discourses (Hasan 2006, 56; Jamhari and Jahroni 2004; Wahid 2014, 27-29). Its return is related to Salafi preachers, who often use the word to denounce the rituals of traditional Muslims, ${ }^{1}$ which, in their view, deviate from the true path of Islam. From their pulpits and through their publications, TV and radio shows, Salafi preachers warn the Muslim population of the danger of bid'ah and the risk of hell for its practitioners; moreover, Salafis urge their Muslim audiences to return to the authoritative texts in religious matters, the Holy Qur'an and the Sunnah of the Prophet Muhammad, and to stay away from any type of innovation.

The term "salaf" means "to precede." A Salafi can thus be defined as one who follows the path of the pious predecessors (al-salaf al-sālih), comprising the Prophet, the Sahabah (Companions), and the Tãbi in (Followers of the Companions). These Muslim generations have been most imitated by later ones. The authority of al-salaf al-șalih has been granted by the hadith, which says, "The best people are those of my generation, then those who come after them, then those who come after them," (narrated by Bukhārī). The Salafi manhaj can thus be defined as those principal teachings promulgated by these early generations, who had been guided by the Prophet. The Salafi manhaj emphasizes the importance of the texts (the Qur'an and the Sunnah) as the most authentic religious sources. The term "salaf" is frequently opposed to "khalaf", meaning "successors", or the later generation", believed to have created various religious innovations.

The return to the Qur'an and the Sunnah, and with it the emphasis on the necessity of following the salafi manhaj - without which a "correct" interpretation of the Quran and Sunnah is deemed impossible by Salafis, is part of a typically Salafi rhetoric and is not a new phenomenon in Indonesian Islam (Abdullah 1971; Federspiel 1970; Noer 1973; Saleh 2001). In the early twentieth century, Muhammadiyah and Persis, modernist Muslim groups that have been influenced by a variant of Salafism rooted in the ideas of Muhammad Abduh (1849-1905) and Muhammad Rashid Ridha (1865-1935), launched a similar campaign. They warned the Muslim community against certain rituals such as $\operatorname{tahli} \hat{l}^{2}$ and ziarah kubur (visiting the 
graves). ${ }^{3}$ The campaign was so pervasive that, for decades, bid'ah issues caused ongoing conflict and a deep division between traditionalists and modernists. This conflict remained in effect until the late 1960s. Along with education improvement, increased social engagement between both groups, and the modernization of Islamic institutions, these issues have disappeared to some extent, and the division between modernists and traditionalists seems to have blurred (Anwar 2009, 349-85; Azra 2005; Burhanudin and Afrianty 2013; Hefner 2000; Mahasin 1999).

This article deals primarily with the reproduction of religious knowledge in contemporary Indonesian Islam. It focuses on issues pertaining to ritual differences between Salafis and traditionalist Muslim groups and how their understanding of rituals relates to larger social and political issues. It will also discuss the roles of mosques in shaping Islamic discourses and how collective rituals such as Friday prayers and tahlìl sessions have recently been politicized. Salafi groups use bid'ah to negotiate with others and, by doing so, allow themselves to exert power over the public sphere. It is a strategic tool that may change over time to address existing social and political contexts.

\section{The Issue of Bid'ab}

A central aim for Salafis is the eradication of bid'ah. The prohibition of practising bid'ah is based on the following famous hadith:

"Of all matters, the worst are innovations; and everything new is an innovation, and every innovation is a deviation, and every deviation leads to Hell-fire" (Hadith, narrated by Muslim).

Salafi groups use this hadith as a primary weapon to attack traditionalists. Time and again they reinstate the danger of bid'ah in their religious discourses. Salafi anti-bid'ah rhetoric re-emerged around roughly the 1990s when graduates from Saudi universities returned home. Although they did not specifically direct the issue to traditionalists, the latter felt that it was directed at them, which took them back to the bitter past when they were accused of being bid'ahpractising Muslims, or, even worse, syncretic. This is felt even more acutely in rural areas where traditionalists and Salafis live side by side. In response to these accusations, traditionalists retaliated by accusing Salafis of being Wahhabis, a pejorative term denoting a model of Islam which is harsh against women; they accuse Salafis of being Saudi Arabian agents who intend to Wahhabise Indonesian Islam (Hasan 
2008, 263-82; Rahmat 2005). Religious disputes between Salafis and traditionalists have been so uncompromising that they have had major consequences for religious harmony in Indonesia. In some regions, the disputes were so frantic that both sides almost resorted to violence.

As the most important Islamic institutions, mosques have become the battleground for Salafis and traditionalists, as both try to exert their influence over Muslims. This is even more the case considering that these institutions are poorly organised. Suspicion of the possibility of mosque misappropriation is often heard. Some studies have found that radical groups use mosques to promote their teachings and to recruit new members (Al-Makassary and Gaus AF 2010, 261-82). Realising that their mosques have become Salafi targets, in early 2005, NU and Muhammadiyah certified their mosques and warned Salafis not to become involved in their businesses. ${ }^{4}$ In urban areas, this concern is maintained by strict regulations issued by mosques management teams. Announcements were made stating that mosques were only open during prayer times, especially at noon, and any public lecture planned to be held should be reported to the relevant management team.

While conflicts and contestation over mosques have frequently occurred within the Muslim communities (Dijk 2013, 15-24; Gaffney 1987, 199-225; Wai-Weng 2014, 175-90), mosque certification to prevent contending claims is a novel phenomenon. On the one hand, it reflects the intensity of the tension between the different Muslim groups in Indonesia. On the other hand, it reveals the prominent position of mosques in shaping religious discourse. Although mosques were never built along religious denominations, such as churches in Christianity, in practice, Muslim groups control their mosques in order to keep them in line with their understanding of Islamic teachings. This gradually forced all Muslim groups to build their own mosques. In the 1950s and 1960s, Muhammadiyah followers in Ciputat, around 15 kilometres from Jakarta to the South, where I have lived for more than three decades, built their own mosques, setting them apart from those erected by traditionalist villagers. Recently, along with urbanisation, new mosques have been built as old mosques were unable to accommodate the increasing numbers of attendants.

The total number of mosques across Indonesia has almost doubled, from 392,044 in 1997 to 643,843 in 2004 (64\%). ${ }^{5}$ In some parts, this increase is attributed to Salafi groups who, as new players, have 
built new mosques to support their movements. With financial support from their Middle Eastern patrons, Salafis were able to build these institutions in many places. If we assume that each Salafi school has its own mosque, currently having around 150 schools, there should be around 150 Salafi mosques across the country. ${ }^{6}$ This does not include Islamic centres and musallá (chapels) built by Salafis. As a result, contestation between Muslim groups over the public sphere has become inevitable. It is relevant to note here that, in Indonesia, mosques are managed in a rather informal manner. Any Muslim with a certain level of religious knowledge is allowed to deliver sermons about themes ranging from religion to politics and, on occasion, mosques have been deliberately used for political mobilisation. Someone familiar with the current condition of Indonesian Islam would certainly agree that, each Friday, when weekly congregations are held in the mosques, Muslim preachers attack each other on a number of issues.

\section{The Roots of Religious Polemics}

Polemics on religious matters are universal and are found in many religions (Bowen 1993, 229-88; Geertz 1976; Woodward 1989). Polemics occur when theologians or religious scholars question the validity of particular religious doctrines or practices. To restore orthodoxy they refer to texts they see as the most authentic sources. In Islam, polemics occur not only in regard to theological doctrines, but also in regard to religious practices. In Indonesia, there is a huge diversity in religious practices, ranging from ablution procedures to the performance of the hajj. The differences are the result not only of the use of different methods, but also of the difference in social settings in which texts are interpreted and their contents practised. The interplay between texts and practices is inevitable. While texts represent the universality of Islam, religious practices represent localities and particularities. This interplay is far from stagnant and changes over time. Muslims constantly interpret and reinterpret the meaning of the texts, leading to the rise of Islamic reform (Azra 2004; Saleh 2001).

More than any other Islamic sect, Salafis are especially concerned with purification (Haykel 2009, 33-51). They are revivalist Muslims who are extremely concerned with reorienting the religious practices of the Muslim community to accord with authentic sources. This principle 
has been emphasised again and again throughout Salafi history. When Islam was deemed under attack by the remnants of Hellenic civilisation, Salafi ulama rose and defended its purity. Ahmad ibn Hanbal (d. 855), the founder of the Hanbali School, was one of the people who pulled back the pendulum of Islam to the texts by turning the hadith into the second source, the first being the Quran, for his jurisprudence method. He preferred the use of a hadith to qiyass (reasoning by analogy) in religious matters, even when its sources are weak. His method contrasts with that of Abū Hanīfah, the founder of the Hanafi School, who placed qiyās (analogy) as his primary method. Because of this, Ibn Hanbal's school is highly literal, leading to the rise of Islamic puritanism, as opposed to the Hanafĩ school, which is highly rational. Ibn Taymìyah continued this spirit of puritanism and he is seen as the founder of Salafism. Much like Ibn Hanbal, Ibn Taymīyah (1263-1328) was concerned with the fact that Islam had been contaminated by alien elements. He called upon Muslims to return to the Quran and the Sunnah. In the modern period, the idea of a revivalist Islam is found in the teachings of Muhammad ibn 'Abd al-Wahhāb (1703-1792), the founder of Wahhabism. Like his predecessors, he called upon Muslim believers to uphold tawhid (the act of believing and affirming that God is one) and to stay clear from blasphemous practices. He lived in the Arabian desert, where such practices as sainthood and saint worship had been ubiquitous. For this reason, he was hostile toward the practices of shirk (polytheism) and idolatry (Al-Rasheed 2008, 22-58).

Intensive Islamisation in the archipelago did not take place until the fourteenth and fifteenth centuries (Reid 1993). Historical accounts record that religious conversion merely included the utterance of the formal confession of the faith, circumcision, and abstinence from consuming pork. The people's behaviour and their religious practices remained largely unchanged and they limited themselves to mystical synthesis (Ricklefs 2006). When Dutch scholars started to study Islam and local culture in the late nineteenth century, they found that the local population practised rituals associated with indigenous religions. In the mid-twentieth century this did not change, as anthropologists who conducted their research at the time learned (Geertz 1960). Based on this historical evidence, it is understandable that, in the early twentieth century, reformist Muslim organisations such as Muhammadiyah and Persis acquired rituals and ritual purification as one of their main 
themes. Blasphemous rituals were stamped out and religious practices were drawn into the significance of the texts.

Bid'ah literally means innovation, a belief or practice that has no precedent in the time of the Prophet. In a hadith, the Prophet Muhammad said, "Whoever introduces into our matters [religion] that which is not part of it, will have it [innovation] rejected." (narrated by Bukhārī and Muslim). In the hadith quoted above, the Prophet says, "Of all matters, the worst are innovations; and everything new is an innovation, and every innovation is a deviation, and every deviation leads to Hell-fire." (narrated by Muslim). Based on this hadith, the majority of the Muslim community believes that bid'ah is prohibited. The problem is that their understandings vary. In regards to this matter, Muslim scholars are divided into two groups. The first group is that of those ulama who argue that bid'ah includes all aspects of ritual that have no precedent neither in the period of the Prophet nor in that of the Companions. Most of the Salafi groups belong to this group. The second group believes that the prohibition of bid'ah only includes those rituals, which are considered bad (bid'ah sayyiah), while good bid'ah (bid'ah hasanah) is permitted. The prominent Shāfīi scholar, 'Iz al-Dīn ibn 'Abd al-Salām (662 H/1262 CE), goes even further. He divides bid'ah into five legal norms depending on whether or not the practice contradicts the texts, judiciary consensus, or the precedent of the Companions. Within this framework, he categorises five types of bid'ah: bid'ah wajjibah (obligatory innovation), bid'ah mahrumah (prohibited innovation), bid'ah mandūbah (recommended innovation), bid'ah makrühah (reprehensible innovation), and bid'ah mubāhah (permissible innovation) (Zamhari 2010, 25-35).

The second conception of bid'ah is quite popular. It was made to accommodate the flexibility of religion and its ability to absorb local elements pertinent to the dissemination of Islam and its survival. Without this conception, the practice of Islam would be rigid. Muslim teachers have practised this model for centuries. This is also why Islam could be easily disseminated in the archipelago, which, prior to its inception, was influenced by Indic civilisations. NU, which claims not only to be their descendants, but also the successors of their da'wah, continued the cultural approaches adopted by the Wali Songo. It is important to say that many practices among the NU can be categorised as "bid'ah," but NU followers argue that they are engaged in bid'ah 
hasanah (good bid'ah), which is necessary as it contributes to vibrant and rich discourses among traditionalist Muslims. For instance, reading the Qur'an with melodious voices is in fact bid'ah since there is no precedent for it. Nevertheless, it is considered good bid'ah rather than blasphemous bid'ah making it not only permissible, but also recommended.

While this typology is useful, in practice it is hard to implement. This is because, first, the boundaries between "good" and "bad" bid'ah are matters of perspective. Modernist and traditionalist Muslim groups have long discussed this issue, but they have hardly ever achieved a compromise. Second, some "bid'ah hasanah," as the traditionalists may have called them, seem to have strayed too far from Islamic orthodoxy. They seem to "contradict" the principles of Islam, which emphasise the balance between material and spiritual life and to refrain from acting in an excessive manner. Based on some sources, it is said that in each haul (annual commemoration) of a local saint in Pati, Central Java, the cloth used to cover the tomb in the previous year has become increasingly expensive. Nowadays, it is auctioned and, in 2012, a wealthy merchant from Surabaya, East Java, bought the cover for no less than IDR 275 million (around US\$26,000). It is said that the garment is used for different reasons. Many accept it as a gift, while others see it as an amulet so that the criteria for bid'ah hasanah are apparently rather fluid.

Over the last decades, the modernist Muhammadiyah has been more lenient in terms of Islamic propagation (Qodir 2010). In 2004, it made an important shift from holding on a puritan method to adopting a cultural approach (dakwah kultural). With this new approach, Muhammadiyah expects that it may become more actively involved in the promotion of Islamic values. This shift is a breakthrough for the organisation, which was previously recognised as a strong-minded reformist stronghold. Despite of this shift, Muhammadiyah followers still distance themselves from certain death rituals and refrain from performing them. They are unlikely to perform ziarah kubur or tabarruk (seeking blessing) by visiting saints' graves. Their main reason is that these rituals might lead to shirk, which in Islam is the greatest sin.

Salafis are even more adamant in denouncing such rituals. This is because, while having no legitimate arguments, rituals surrounding the death could potentially disturb and even harm the concentration of the believers while they worship God. In many religious sanctuaries, 
Salafis argue that instead of seeking God's blessing, people seek the help of dead saints, which is unacceptable. This is also the reason why Wahdah, a Salafi organisation in Makassar, reminds its followers to be careful when they perform ziarah. During my fieldwork in 2012, one of its officials said:

If you visit the grave of a saint, you will see many things, which potentially may shift your concentration away from worshiping God. You see a tomb, offerings, incense, etc. That is not to mention that men and women mix, which is strongly prohibited. You also see people weeping and retreating inside the grave's compound for certain periods of time. They [the pilgrims] say that they don't worship the graves, or the saints. They just seek God's blessing. Ok. However, if they really seek blessings, why do they need to come to the graves? Blessings can be attained through performing religious obligations, reading the Qur'an and praying, etc. With these elements in the background, they may slip away from the correct practices of ziarah and fall into the practice of shirk. This is the problem. I love ziarah because it is recommended by the Prophet. It reminds people that one day they too will die. But we are concerned with the fact that the existing practices are against the Sharia.

Based on this interview, it can be concluded that Salafis refrain from practising any ritual that could cause their concentration to deviate from worshipping God alone. This conclusion is rejected by traditionalists, who believe that they neither worship saints nor worship at their graves.

\section{Upholding Tawhīd and Fighting Polytheism}

It is obvious that the Salafi campaign against bid'ah is related to more fundamental issues: menegakkan tauhid (upholding tawhid) and memerangi kemusyrikan (fighting polytheism), which are the main concerns of revivalists. Many Salafi figures assert that performing ziarah, as can be seen in many places in Indonesia, tends to deviate from the Sharia; most likely, visitors believe that blessings may be attained through the saints' intermediacy, which is unacceptable. Salafi preachers vehemently attack the existing practice of ziarah. On many occasions, they state that Islam urges its followers to worship God directly and does not recognise any intermediacy, which is a remnant of pagan religions, where, to simplify matters, people worship God in indirect ways through third parties. This is exactly what the Qur'an says about the Meccan polytheists. Having been asked why they worship idols rather than Almighty God, they responded: "We only worship 
them so that they may bring us closer to Allah in position" (QS 3: 39). The Salafis further argue that the remnant of this pagan religion was transformed into the tawajjuh doctrine (imagining the face of the master for spiritual transmission), where a follower of a mystical brotherhood starts his mystical journey by imagining the face of the master (Trimingham 1971, 211).

An instance of the practice of ziarah in Indonesia can be seen in the story of Imron, a Salafi ustädh from Ciputat, about 10 kilometres from South Jakarta, who enjoyed visiting the graves of saints when he was young. When I visited him in his office on a sunny afternoon, he had just finished teaching at his madrasah. He asked me to follow him into his office. He recalled the time when he was still in a state of jähilìyah (ignorance of divine guidance), by which he meant the period when he had not yet joined the Salafis.

Arriving at the grave of Sultan Hasanuddin in the 1990s, who was a Muslim saint and the founder of the Banten kingdom, he saw something that he has not forgotten. The sanctuary was heavily crowded, notwithstanding that it was already $10.00 \mathrm{pm}$. Inside the compound, men and women formed a long line for their turn to be seated. The grave was sheltered by an iron platform and adorned by a beautiful green velvet cover decorated with gold Arabic script. From outside, beggars came rushing in. They shuffled among the attendants in the hope that the attendants might provide them with small change. He then realised that it was the month of Sha'ban, (Ind. ruwah, originally from the Arabic word arwāh meaning spirit). It is common that during this month, the local Muslim population visits the graves of their relatives and local saints. What surprised him was that the people sitting in the grave compound wore dirty clothes and that some were even asleep on the floor. Driven by curiosity, he joined the crowd and tried to talk with them. Later, he discovered that they were performing nazar (making an oath to perform good deeds) for different reasons. Some had been there for days and others even for weeks. Some were hoping to have children, while others wanted to have a spouse, be promoted, or acquire significant wealth.

On another occasion, Imron recounted his visit to the grave of Sunan Gunung Jati, one of Java's nine saints in Cirebon, West Java. There it was even more ominous. This is because Chinese religious paraphernalia was also present in the compound. According to the legend, the saint 
was married to a Chinese woman named Ong Tien, whose grave is located on the other side of the compound. Many Chinese pilgrims prayed at her grave, which was fully decorated with red and yellow Chinese lampions. The smell of burning incense was strong and had made him feel unwell. He left the compound immediately. Outside, in the parking lot, preman (unauthorised parking officials) demanded high prizes for guarding vehicles. Their voices mingled with those of street vendors, who were busy offering their merchandise to visitors. He was haunted by the question of how to explain what he had seen but there seemed to be no answers to his questions. When he started to join the Salafi halqah (religious gathering), he told this story to his teachers. They said that these practices amounted to shirk, and shirk was identical with disbelief.

The terms shirk and käfir or kufr are extremely serious and Muslim groups generally understand this. In earlier times, modernists hardly ever used these terms in their attacks against traditionalist Muslims. Instead, they used the abbreviation TBC, meaning Takhayyul (superstition), Bid'ah, and Churafat (belief in supernatural beings). With this term, the former wanted to compare the latter to contagious, but curable, tuberculosis (TB). In earlier times, the public perception towards this disease was so bad that its victims were isolated. By comparing the practitioners of bid'ah to TBC patients, the modernists provoked their Muslim audiences to stay away from these, in their eyes, ridiculous practices (Abdullah 1971; Federspiel 1970; Noer 1973; Saleh 2001). It also revealed the backwardness of the traditionalists who did not have access to public health institutions to seek cures for their patients. In response to the modernist accusation, the traditionalists did not use the term käfir or shirk. Instead, they used the term "anti-tahlìl", meaning that they do not want to pray for their deceased relatives. It was accompanied with the statement "as if a dog, not a human being, just died." This statement had a significant impact on the Muslim people because, within the Muslim community, dogs are considered impure and Muslims do not want to die like an impure dog. To prevent their passing relatives from being understood as dogs, they held tahli $l$ rituals. It was also believed that tahlil is the last thing family members can do to please their passing relatives in the Hereafter.

Salafis currently use the term käfir (literally meaning obliterating, covering, ungrateful, roughly glossed as unbelievers or disbelief) to 
denote those Muslims who enact rituals that potentially lead to shirk. In the Quran, the term käfir and its derivatives are mentioned repeatedly, signifying their danger from which all the believers should seek God's protection. Its meaning, 'to cover', refers to a pre-Islamic practice when farmers buried seeds in the ground and covered/hid them with soil while planting. Käfir and kufr thus imply concealment and coverage. It is used to describe people who cover their hearts so that they are unable to comprehend God's truth (QS 2:7). The term is further used to denote the Meccan polytheists and the Ablal-Kitäb, comprising Jews and Christians, who do not accept the prophecy of Muhammad (QS 98:1). In Islamic history, the term kajfir was used for the first time by the Khawarij, a splinter group who, in the aftermath of the Battle of Shiffin (657 CE), accepted neither the political leadership of 'Alī ibn Abì Ṭālib, the fourth caliph, nor that of his challenger Mu'āwìyah ibn Abī Sufyān, and regarded them both as käfir because they did not follow the Quran and the Sunnah. In the modern period, revivalist Wahhabis use the term to denote fellow Muslims who practise various forms of bid'ah.

It is important to note that Muslims accusing other Muslims of being käfir is an unprecedented phenomenon in Indonesia. Its use by Salafis inevitably brings about, on the one hand, a deep divide in inter-religious relations within Muslim groups. On the other hand, it crystalises a religious schism and sharpens social and political friction. A number of conflicts with varying degrees of violence have taken place. Predictably, the main battle took place between Salafis and traditionalist groups. Feeling under attack by Salafis, Said Aqil Siradj, a top NU executive, has made a list of Salafi foundations that promote religious extremism. He even thinks that Salafi ideologies are a real threat to national integration and he demands that authorities cease receiving financial support from the Middle East. ${ }^{7}$

To a lesser degree, a battle is also taking place between Salafis and moderate Islamic institutions such as IAIN (Institute Agama Islam Negeri-State Islamic Institutes) and JIL (Jaringan Islam LiberalLiberal Muslim Network). In 2002, Hartono Ahmad Jaiz, a Salafi preacher and writer, accused the IAINs of promoting apostasy among their students (Jaiz 2002). This is because, as he believes, the institutions teach liberal thinking to their students, leading them to be lax in the execution of their religious obligations. This attack is not new. The institutions have been the targets of criticism by Islamists 
for a long time. They are considered secular institutions that merely poison the minds of the young Muslim generation. As to JIL, the FUI (Forum Umat Islam-Muslim Community Forum), a Salafi-Islamist group in Bandung, West Java, condemned Ulil Abshar Abdalla, the JIL coordinator and young NU intellectual as being an apostate whose blood may legitimately be shed. It is relevant to note that JIL, a forum which regularly holds seminars and conferences on interfaith dialogue and pluralism, cooperates with Muslim and non-Muslim partners. Its presence has provoked Islamist groups as they think it promotes secularism and liberalism within the Muslim community. Ulil's condemnation reflects the bad relationship between Islamists and moderate Muslim groups in Indonesia (Anwar 2009, 349-79).

The Shiites and the Ahmadis are also the subjects of Salafi condemnation. Salafis regard Shiites as kaffir on the basis that they defame the Companions. Shiites have defamed all the Companions except 'Ali ibn Abī Ṭālib and his followers. At a higher level, this issue is not only about the relationship between Salafis and Shiites, but also about Sunnites versus Shiites. It is about the dispute over the issue of authority after the Prophet Muhammad's death. From this historical polemic, conflicts have spilled over into politics. Throughout history, there has been a long list of conflicts between both groups. Salafis nowadays accuse Shiites of masterminding many political conflicts in the Middle East, where a great number of Sunnites have been killed. Shiites, on the other hand, accuse Sunnites of being the puppets of Middle Eastern authoritarian rulers. Finally, Salafis also regard the Ahmadiyya as a non-Muslim sect and accuse Mirza Ghulam Ahmed, its founder, of being a fake prophet. Together with other Islamist groups, Salafis demand that the Ahmadiyya should proclaim itself as a nonIslamic sect (Burhani 2013).

It is clear that issues of bid'ah move easily from the religious domain to the social and political. It disturbs religious harmony and majorityminority relations. It also spurs the rise of radical movements. Hate speeches against minority groups such as the Ahmadis and the Shiites may provoke ordinary Muslims to resort to violence. On the other hand, it interrupts the reproduction of a strong Islamic discourse. The question, however, is why Salafis use the term käfir against their opponents and under what circumstances did the term come to be used? 


\section{Käfir and Shirk}

Salafis have used the terms käfir and shirk for centuries, and more than any other book, Kitāb al-tawhìd written by the founder of Wahhabism, Muḥammad ibn 'Abd al-Wahhāb, is the most important work that deals with these issues. In Saudi Arabia, the book has been used as the main reference for religious teachings, shaping the Salafi ideological formulation. Through the alumni from Saudi Arabia who took it home with them, this book was further introduced to other parts of the Muslim world. The book is used in Salafi schools throughout Indonesia. While many sources have been replaced by new ones, this book has been maintained for decades. It is almost irreplaceable as it contains the most fundamental principles of Salafi teachings. Its greatest feature rests in its simplicity. Each chapter and sub-chapter are written in a very systematic way, very much like guidelines, and are complemented with verses from the Holy Qur'an and the hadith of the Prophet Muhammad, and a glossary of difficult words.

Muhammad ibn 'Abd al-Wahhāb’s thoughts were very much shaped by his living conditions. He was born in Uyainah, a rural area in central Arabia (Al-Rasheed 2008, 14-38). Where he lived, Islamic practices were mixed with mystical elements and mystical associations, which strongly contaminated the purity of tawhid. People sought a sheikh's blessings, and he gave them talismans and amulets. The graves of saints became objects of worship. Islam was practised in such a badly polluted manner that it made him write the Kitāb al-tawhìd, dedicated to cleanse tawhid from shirk, the association of another godly being apart from God. In the pre-Islamic period, shirk was symbolised by the presence of idolatrous deities and, in later times, it transformed into various other forms such as the use of amulets and magic words. In relation to this Ibn 'Abd al-Wahhāb explains in his book:

"From Mu'âdh ibn Jabal he said: I was bringing the Prophet Muhammad on my donkey. He said to me: Oh, Mu ādh. Do you know the right of God from his servant? In addition, what is the right of servant for his God? I replied: God and His messenger know best. He said: the right of God from His servant is that servant should worship Him and not make any associate with Him. The right of servant from God is that God will never punish those who never make associate with Him (al-Wahhāb n.d., 53)."

“... From 'Imrān ibn Husayn, he said that Prophet Muhammad saw a man and there was an amulet on his hand. The Prophet asked him: What is this? The man replied: This is the amulet from a witch. The Prophet 
said: Take it off, take it off. It will never give you anything except anxiety and fear. If you die, that's still on your body, you will become a loser (alWahhāb n.d., 56).”

"From Ibn Mas'ūd he said: I heard the Prophet Muhammad PBUH saying: Talasim $^{8}$ and tamimah ${ }^{9}$ are shirk." (Narrated by Aḥmad and Abū Dāwud)."

Ibn 'Abd al-Wahhāb was particularly concerned with practices that potentially might harm the purity of tawhid. He strongly opposed philosophy because it uses logic, and mysticism and mystical brotherhoods were rejected as they employ the notion of intermediacy; adepts develop their mystical or spiritual experience through the intermediacy of a shaykh. Ibn 'Abd al-Wahhāb found these practices unacceptable. Spiritual experiences can be attained through performing standard rituals such as prayer and not through mystical speculation. The revivalist Wahhabis have taken up the themes of käfir and shirk in their lectures and they repeatedly discuss them to remind all Salafi members of their dangers. On many occasions, Salafi preachers pick up these themes in front of large Muslim audiences, and from the pulpit, the words käfir and mushrik (polytheist) flow easily from their mouths. If there is hate speech in the Islamic discourses in Indonesia, Salafis may have contributed to its existence. They have been using these words so often against other Muslim groups that a so-called Salafi Takfiri has emerged. Bin Bāz (1910-1999), a contemporary Salafi scholar and the great muftì of Saudi Arabia, believes that Ahmadis are kāfir:

"Qadianis are käfir because they believe that Ghulam Ahmad is a prophet and in possession of a revelation. This is against Islamic principles. They oppose Allah and His Messenger. They are käfir even though they fast, pray, and believe that they are Muslims (Majmūāàt Fatāwá Bin Bāz n.d., 39)."

Qadianis constitute a group of Ahmadis, who allegedly believe in the continuation of the prophetic revelation after the Prophet Muhammad. Their presence has raised controversy among Muslims. In 1982, the World Muslim League (MWL) issued a fatwá, inspired by Bin Baz's opinion, that the Ahmadiyya is not an Islamic sect, but it nonetheless had great influence in the majority of the Sunni Muslim countries, which were MWL members. Over the last decades, violence against Ahmadis has escalated in Indonesia and they have become the target of religious radicalism. This escalation was prompted by, among others, Salafis who had revitalised the fatwá. 
Not all Salafi groups agree with the persecution of the Ahmadis. Some even argue that the use of the term kafir is the prerogative of God, as only God knows about people's imān (faith). They agree that Ahmadis deviate from the true path of Islam but that it does not mean that they should be prosecuted. The Wahdah Islamiyah, a Salafi organisation in Makassar, believes that Ahmadis should be advised to return to the right path of Islam. At the same time, Wahdah reminds all Muslim groups to maintain good relations not only with Ahmadis, but also with other Muslim groups including Shiites.

\section{Purification versus Capitalisation}

Salafis perceive bid'ah as an absolute concept. Piety is achieved through performing standard religious rituals, such as praying, fasting, and reading the Qur'an. This is so-called Sharia's piety as opposed to traditionalist Muslims' mystical piety (Woodward 1989, 2011). Salafis totally reject rituals such as tahlill, ziarah kubur, and the celebration of religious festivals. Salafis, who forcibly attend rituals organised by traditionalists, as frequently happens in neighborhoods where Salafis and traditionalist Muslims live side by side, would remain quiet during the entire proceeding. They would refuse to recite a single prayer throughout the ritual. The absence of these rituals among Salafis has major implications. Compared to traditionalists, Salafis have more funds that they can use for different purposes. This fact, in some part, helps us to understand the survival of Salafi groups over the last few decades, when financial support from Middle Eastern countries has been decreased significantly. Driven by piety, the available funds are thus geared towards the establishment of educational and social institutions, and for other programs deemed useful for their members. Nevertheless, their abstinence in performing collective rituals, on the other hand, impoverishes social engagements among them because, as we will soon see, collective rituals serve as a means to produce social networks and to empower civic networking.

Contrary to the rituals of Salafis, the rituals practised by traditionalists are fluid. In doing so, they tend to link rituals to larger social and political problems, from which they derive benefit. This is what I call the capitalisation of ritual. Tahlill, for instance, is a collective ritual. It consists of reading Sürah Yäsin and uttering various prayers and it lasts only around thirty minutes. In practice, this simple ritual can turn 
into an effective means of social engineering. The elders and the village officials are always present among the attendants. Young people attend the rituals for other reasons. This is even more so as big meals called kenduri are served (Bowen 1993, 229-50; Geertz 1976; Hefner 1985, 104-25; Muhaimin 1995).

After the ritual has finished, the attendants turn their attention to something else, namely social and political issues. ${ }^{10}$ It is clear that people participate in the ritual not only for religious reasons. They also use it as an excellent way of socialisation. New ideas are usually shared during these conversations. Elders with much experience and knowledge would begin the conversation by talking about particular issues pertinent to the interests of the villagers and they may relate to the weather and the late rainy seasons leading to drought across the village. Other attendants respond to these issues by saying that experts have warned about global warming and the greenhouse effect, among other issues. On other occasions, the conversation may be related to local politics and that the incumbent village chief (pak lurah) will run for another election, but he seems to have been challenged by a new, young contender. Along with the conversation, jokes are heard. The conversation would likely end when an elder stands up signalling to the rest that the host needs take a rest. This informal conversation seems trivial, but various studies have indicated that the institution of tahli $i$ has contributed to a solid civic culture among the traditionalists (Mujani 2003).

Besides tahlill, the commemoration of haul has also become an effective means for social and political mobilisation. This is even more so when the ritual is held to celebrate local saints or prominent leaders. The haul of the late former president and prominent leader of Nahdlatul Ulama (NU), Abdurrahman Wahid, which takes place in December, has turned into an occasion for social and political mobilisation. Thousands of people come to his residence in Cianjur, South Jakarta, including ordinary Muslims, bureaucrats, politicians, and businessmen. Approaching the general election of 2014, during the last haul in 2013, politicians seemed to compete to win the votes of traditionalist Muslim groups, which constituted around 50 million people nationwide. Furthermore, as Abdurrahman Wahid worked to assist the ethnic Chinese minority, their representatives were also invited to attend the ritual. 
When I was still in a pesantren in Cirebon, West Java, in the 1980s, the commemoration of the haul of the founders of the pesantren attracted thousands of visitors. Students, alumni, and members of the local population were invited to the pesantren. Bureaucrats, politicians, and celebrities were also present. Approaching the event, the pesantren was decorated, and some renovations were made, to celebrate this significant event. A large stage was erected in front of the Grand Mosque where guest speakers would deliver their speeches. Meanwhile, along the road to the pesantren, vendors had set up their stands offering various goods to the visitors. During the proceedings of the haul, which was usually held after the Friday sermon, all attendants visited the graves of the founders of the pesantren to pray for one hour. Afterwards, many visitors stayed in the pesantren because they wanted to see the kyai and ask him all sorts of questions on religious matters. Others used the event to visit old friends who had previously studied in the pesantren and who had gone on to have successful careers. The conversation varied greatly, ranging from family matters and jobs, to a proposal of establishing a madrasa. At a higher level, talks could relate to political support and the economic crisis.

\section{The Politics of Ritual}

Politics of ritual refers to holding a ritual in a given context where actors use the occasion as a means to negotiate with, and exert power over, other groups (Bowen 1993; Hefner 1985; Peacock 1978). Some rituals are deeply embedded in the history of the ethnic groups who perform them, while others are newly imported. The Gayo ethnic group in Aceh would argue that healing or harvesting rituals are specific to its society, which makes any conversation that challenges their legitimacy highly unlikely (Bowen 1993, 229). Meanwhile, the Hui Muslim ethnic group in China developed its nationality through rituals, which debunks the homogenous notion of China-ness (Gladney 1998). In Java, the politicisation of rituals has taken place over centuries. Social grouping is made along ritual practices.

Clifford Geertz divided Javanese society into three different variants: santri, abangan, and priyayi (Geertz 1976). Santri are basically pious Muslims associated with Javanese trading activities. The connection between Islam and trade has a long history. It goes back to the Islamisation of the archipelago in which Muslim traders played 
important roles. Many rich traders managed to make the pilgrimage to Mecca and to set up religious institutions, such as mosques and madrasah. The main social institutions of the santri, therefore, besides the markets, were also mosques, pesantren and madrasah, and by these institutions the santri developed rituals based on those of the santri.

Abangan are basically of rural origin, are peasants, mostly illiterate, and relatively poor compared to santri. The main social institutions of the abangan are households, rice fields, and villages. Over time they managed to preserve various animistic aspects of Javanese syncretism that were broadly related to peasant elements. The abangan are Muslims. Since they belong to different social institutions, however, they do not place too much emphasis on Islamic rituals. Their numbers decreased significantly over recent decades as a result of intensive Islamisation (PPIM UIN Jakarta 2004).

Priyayi stem from the Javanese hereditary aristocracy. In the colonial period, they served as salaried civil servants. They preserved a lifestyle that was close to that of mystic synthesis, a mix between Sufism and Javanese monism and pantheism.

In Indonesia, traditionalists, modernists, and Salafis have all been involved in the politicisation of rituals as they are part of their identity markers. In previous times, it was easy to find out if someone was a modernist or traditionalists by asking questions like: Does he read the qunut or not? ${ }^{11}$ Does he hold tahlil or not? Does he visit graves or not? If the answers were "yes," it could be ascertained that he was a traditionalist. ${ }^{12}$ In previous times, traditionalists performed the taräwih, comprising 23 raka'ah (cycles, 20 raka'ah taräwih plus 3 raka'ah witr), while modernists performed 11 raka'ah (8 raka'ah tarāwih plus 3 raka'ah witr). The issue of taräwih raised fierce debates and even caused conflicts between the two groups. Around the 1980s, many traditionalist Muslims started to perform the taräwiz with 11 raka'ah. This does not mean that they became modernists; indeed, they remained traditionalists. To support their arguments, however, they proposed the idea that Muslim scholars had set out reliable argumentations for both traditions (23 raka'ah and 11 raka'ah).

During the month of Ramadhan, when salat taräwih is performed for the entire month, religious groupings of traditionalists and modernists are inescapable. Modernists will perform the salat in modernist mosques, and traditionalists in traditionalist mosques. 
In areas where religious denomination is not particularly important, such as on university campuses, mosques will allow the performance of salat in two different ways to allow both groups to discharge their service. Therefore, after completing 11 raka'ah, modernists will stand up and leave the mosque, while traditionalists remain in the mosques and continue their prayer until they have finished 23 raka'ah. This phenomenon is hardly ever found outside university campuses, as each mosque is controlled by either modernists or traditionalists.

While the people's perception of some rituals has changed, their perception of other rituals has remained the same. This holds true for traditionalists with regard to tahlìl and ziarah kubur. Traditionalist Muslims continue to practise these rituals to this day, while modernists categorically refuse to practise them. Tahli l is the most important variable that distinguishes traditionalists from modernists. Conversely, the use of hisäb (astronomical calculation) in determining the coming of the months of Ramadhan and Shawwal for celebrating Idul Fitri, has been the trademark of modernists, while traditionalists use ruyah (sightseeing) in these instances. Modernists, particularly Muhammadiyah members, still employ this method. It often happens that Muhammadiyah followers, applying hisāb, celebrate Idul Fitri one day earlier than the majority of the Muslim population, which follows the stipulations of MORA (Ministry of Religious Affairs), a government institution that is authorised to determine the end of the fasting month. When the Minister is a Muhammadiyah cadre, however, Muhammadiyah and the government celebrate Idul Fitri on the same day.

The controversy surrounding rituals re-emerged with the arrival of the Salafis. The obvious political reason behind this move is that, through rituals, Salafis not only define themselves, but also exert their power over others. The politicisation of ritual largely occurs during collective rituals that have public effects. More than any other rituals, Salat Jum'at (Friday Prayer) is the most effective opportunity to exert influence as it is held weekly and involves a large segment of the Muslim population. It is important to note that mosques are places of worship, as well as symbols of unity that link individuals with the community.

Salat Jum'at (Friday prayer) is a collective ritual in which various symbols are highly contested, such as the first adhān (call to prayer). Some Muslim groups make the call while others consider it bid'ah. It 
is relevant to note that the origin of the first adhan is not based on a hadith of the Prophet Muhammad, but rather on a decision made by Caliph 'Umar ibn al-Khațāa (the second caliph). Given the fact that the Muslim community had grown larger and had become dispersed over a large area during his reign, the second adhān, the original one, made when the khätib (preacher) was about to deliver his sermon, was considered not effective enough as a call to summon the people. The caliph proposed the idea of turning the first adhann into an early call, so that the Muslim population had enough time to prepare and go to the mosque to be on time for the prayer. When he expressed this idea, everybody agreed. Since then, the second $a d h \bar{a} n$ has become institutionalised. When modernists were on the rise at the beginning of the twentieth century, they disregarded the first adhann because Friday prayers are always held at around $12.00 \mathrm{pm}$. In every modernist mosque in Indonesia this rule has been maintained by signalling to the congregants that the mosques belong to modernists. Conversely, the traditionalist NU does not only call the first adhān, they also use a bedug, a drum made from buffalo or goat skin, to signal praying time. Although modernists attacked the use of this instrument, it has become one of the symbols of traditional Islam, which has survived to this day.

The contestation over symbols in Salafi mosques is even more intense. There is no first adhān, nor is it signalled by sounding the bedug as they consider both to be bid'ah. Around an hour before prayer time, all activities are ceased. Around $12.00 \mathrm{pm}$, a mu'adhin (caller to prayer) rises and he sounds the adhān. Afterwards, a preacher stands ready to deliver his sermon. Salafi preachers can be distinguished from their traditionalist and modernist counterparts by their physical appearance. They sport a beard and often have a black forehead. Many of them wear a Saudi thawb and a turban. The most important hallmark of a Salafi sermon takes place in its introduction.

All thanks and praise is due to Allah, Whom we thank, from Whom we seek help and forgiveness. We seek refuge with Allah from the evils within ourselves. Those whom Allah guides will never be misled and those whom He misguides will never find one to guide him. I bear witness that there is no deity worthy of worship except Allah and that Muhammad is His servant and Messenger. The best words are the words of Allah, and the best guidance is the guidance of Muhammad. Of all matters, the worst are innovations; and everything new is an innovation, and every innovation is a deviation, and every deviation leads to Hell-fire. 
This is the common introduction of a Friday sermon in Salafi mosques. The preachers call upon the congregants to adhere to the book of Allah and to the guidance of the Prophet Muhammad. While this introduction can be found also in traditionalist mosques, the warning against all forms of bid'ah is a typical Salafi feature, which they derive from the sermon of the Prophet and the Companions. This form is almost never found in traditionalist mosques. The introduction of the sermons in traditionalist and non-Salafi mosques varies greatly and the preachers use various sources to make their sermons interesting.

Salafi preachers begin their sermon by praising God and by reading the salawah (prayer to the Prophet Muhammad). They do not use the word "sayyidina (our leader) before the Prophet's name. Using "sayyidin $\vec{a}$ " is also one of the differences between Salafis and traditionalist Muslims. They further continue their sermon by saying that Muslim believers should fear Allah wherever they are as Allah witnesses what they are doing. Unlike traditionalist Muslims, who seek to interpret the sacred books, allowing them to add explanations to the texts, Salafis, placing much emphasis on these texts, do not. Throughout his sermons, the preacher quotes the Quran, the hadith, and the opinions of Salafi ulama.

Contrary to followers of the Shāfi'i madhhab, to which the majority of Indonesian Muslim adhere and who read the basmalah (the shortened form of the phrase bismillāh al-rahmann al-rabìm) aloud when they read the Fatihah, Salafis, who are much closer to the Hanbali madhhab, do not. They read it in a soft voice and they also do not read it when they read the Sürah (chapter). Many congregants place their hands above their chests to the left, the location of the heart, spread their feet and turn their face right to the spot of the sujüd (bowing). It seems that Salafis bow much longer and push their heads even harder to the floor than traditionalist Muslims. This causes a blackening of two spots on their forehead. ${ }^{13}$ Non-Salafis tease them about this, saying that the black spots on their foreheads do not necessarily guarantee their quality of faith. Traditionalists argue that these traces of sujüd (QS 48:29) point to the believers in the Hereafter when their faces will light up due to their happiness because they encounter God. They argue that Salafis strike their foreheads on their prayer rugs during their prostration on purpose to blacken them, whereas Salafis defend themselves by saying that, referring to the prayer of the Prophet Muhammad, prolonged prostration is highly recommended. 
Salafis make their saf (line) really tight and straight until their feet touch and they even step on the feet of the others. Some imam (prayer leader) would even inspect the lines and correct them before the prayers begin. Curved line-ups mean disunity and Satan would fill the empty spaces. It is said that the Muslim ummah is like "a firmly joined structure" (QS: 61:4). Salafis will not start their prayers until all the attendants are in the right position. "Straighten your line, for it is essential for making the prayers correctly." (narrated by Bukhārī)

Unlike traditionalist NU that has institutionalised wirid (chanting and litanies) after collective prayers, Salafis do not. One by one, the attendants stand up and leave. It is said in the Qur'an that when the prayers have been made, the people should spread out on earth and seek the bounty of Allah (QS 62:10). In addition, they do not shake hands after prayer. Some even make a signal with their hands as if to say, "please do not shake my hand", when an outsider joins their rituals. While shaking hands is considered sunnah (recommended), shaking hands immediately after prayers is considered bid'ah. They say that there is no hadith that states that the Prophet shook hands after prayer. In many Salafi mosques, there is even a list of things considered bid'ah hanging on the wall, one of which is shaking hands after prayers.

\section{Embattling Mosques}

Realising the strategic roles mosques may play, Salafis, in the late 1990 s, began to build their own mosques. In the beginning, mosque construction was made possible by Middle Eastern donations, most of which were reportedly intended for mosque building purposes. This fits with the Prophet Muhammad's words that "Whosoever creates a mosque in this world, God will create a house for him or her in Heaven" (narrated by Ibn Mājah). For this matter, Salafi groups create a section within their organisation, which specifically administers the donations for mosque construction. The amount of money required varies between IDR 40 million (about US\$4,000), which is enough for a small mosque, and IDR 200 million (about US\$20,000), which is sufficient to build a medium-sized mosque.

The construction of a mosque, however, is not necessarily as easy as one may think because of the role of mosques as symbols of unity of the Muslim community. The presence of a mosque in any given settlement is important to enable Muslim men to perform their obligatory Friday 
prayers. When there are 40 male Muslims in a given settlement, they are obliged to perform the Friday prayers in their own settlement. This means that when this number is reached, a mosque needs to be constructed. When there are fewer than 40 Muslim men, they should perform their prayers in a mosque in an adjacent settlement. With this requirement, a new mosque is rarely constructed as long as it is able to accommodate the number of the congregants in the area or as long as there is only one Muslim settlement. Instead of creating new mosques, Muslims are more likely to renovate and enlarge already existing ones (Al-Makassary and Gaus AF 2010, 317-57).

In order to be able to construct their own mosques, Salafis tend to create new settlements relatively separate from local non-Salafi Muslims. Salafis establish their own enclaves where they create their own institutions, such as schools and boarding schools. In this way they are able to avoid tension or even conflict with the local Muslim population. They also require Muslim groups who seek their donations for the construction of a mosque to build that mosque at least one kilometre away from the neighbouring one. This distance slightly varies from place to place, depending on the density of the population. In most parts of Java, particularly in densely populated urban areas, the construction of mosques is relatively easy and each Muslim group can create their own mosque. This is particularly true for new housing and apartment areas that arise in many urban areas, which indeed have their own mosques. Outside Java, this may be different. In Aceh, for instance, the regulation of one mosque for one settlement is still maintained and this prevents Salafis from penetrating urban areas (Sabirin 2009).

In general, Salafi mosques are different from the mosques of other Muslim groups. They emphasise function over structure. One unfamiliar with Salafis would assume that their emphasis on functional features is due to limited budgets, but this seems not to be the case. In many areas, where Salafi groups have stronger financial resources, these features are still maintained. The construction of the Wahdah Islamiyah mosque in Makassar commenced in 2005 and remains incomplete. Its architectural style is simple. This two-floor mosque can accommodate 1000 congregants. The first floor is used for offices and a study room, while the second floor is for prayer. Doors and windows remain uncarved and are painted in one or two bright colours. The walls and ceramic tiles are brightly coloured to give an impression of peace and 
tranquility. There is only one square flat space inside the mosque and no calligraphic ornaments. Salafis consider ornaments bid'ah because they might disturb people's concentration during prayer. A wall clock is placed close to a simple niche to indicate the five prayer times.

Salafi mosques are mostly named after their main donors and thus often carry Arabic names, for instance, the Zayd ibn Hammād Mosque and the Muna al-Farsi Mosque. Some mosques are named after Salafi scholars, such as the Jāmil al-Raḥmān Mosque. While these names work well within Salafi settlements, they may not work for mosques in nonSalafi settlements. The names of non-Salafi mosques are derive mostly from al-Asmä al-Husná (The Most Beautiful Names of God), such as Bayt al-Rahmān (the House of Beneficent), al-Nür (the Light), and Bayt al-Rahim (the House of the Merciful). Given that Salafis provide the funds for mosque construction, as happens in some cases, they adorn the mosques with Salafi names. This raises criticism from nonSalafi groups who also use the mosque. This conflict may be resolved by inscribing the names of the donors on the corner of a wall, while the official name of the mosque is taken from al-Asmä al-Husná.

Salafis would claim the mosques they fund are Salafi mosques, notwithstanding that the local Muslim population around it is not Salafi. As a result, they regularly send their preachers to these mosques to instruct the local population about "true" Islam. These preachers prioritise lessons in tawhid and they combine their instruction with hadith, especially those related to the everyday practices of the faith. By using this strategy, Salafis actually seek to reorient the religious perspective of the local population and to rid it of alien practices. When the people have been sufficiently introduced to tawhid, the next step is that the Salafis invite their audience to discuss issues of bid'ah. This is difficult and sometimes leads to misunderstandings. The local population may oppose this teaching, especially when they think that it is offensive to its own religious practices. Ustadz Hasyim of Wahdah Islamiyah in Makassar admits that he has been working in a local mosque for more than fifteen years. Initially, his audience comprised only a few people, but now his lectures are attended by hundreds of Muslims.

\section{Ritual and Social Practices}

John Bowen explains that during his fieldwork in Aceh he had to attend many rituals (Bowen 1993, 230). The frequent performance of 
rituals has financial consequences, which influences many social and political aspects of the community. Robert W. Hefner asserts that the Tengger community in East Java performs rituals to distribute wealth over all the villagers and to maintain the high status of the performers (Hefner 1985). Both scholars argue that the celebration of rituals is closely connected with social practices. In the following section, I want to take a look at this issue in a different way by comparing Salafi and traditionalist approaches to rituals and their impact on social practices. This aspect is very interesting as it offers a more reasonable explanation of what lies behind the conception of bid'ah.

Because of their own strict regulations, Salafis do not have other ways to express their rituals except through salat, the most important ritual in Islam. Salafis have made prayers the only means to express their mood and mode of spirituality. The mood spirituality refers to the disposition of prayer, while the mode of spirituality refers to the ways of expressing the spiritual need. As a result, they intensify their prayers. This intensification is made by amplifying each phase of the ritual, the number of raka'ah, and the number of prayers. Many Salafi members reportedly perform salat malam (night prayer, which has no limitation, in the high performance). They fast during the day and read the Qur'an in their spare time. They carry a pocket-size Qur'an wherever they go, something traditionalist Muslims rarely do. This is not to say that traditionalists are less spiritual or less pious than Salafis. Traditionalists have their own spirituality that comprises, besides standardised rituals, wirid (chanting), salawah (praise to the Prophet of Muhammad) and, more importantly, they are often members of a mystical brotherhood who practise a set of rituals Salafis categorise as bid'ah.

The intensification of ritual has led, as it were, to the accumulation of spiritual energy within Salafi circles, which they show in their physical appearance. Compared with ordinary Muslims, Salafis are generally quiet but vigilant in terms of the performance of their religious obligations. The question is more about how Salafis release this energy. Salafis are likely to express their energy through certain practices, including charity either in the form of money or precious properties, and they can do this because they spend less money on rituals. Contrarily, the practice of charity among traditionalists is relatively poor as they spend more on rituals. The more rituals a religious group performs, the less they spend on charity and vice versa. 
In the following section, I offer two stories taken from my fieldwork on how highly ritual affects charity practices.

Uthman Sholeh is a Salafi ustädh and the leader of a Salafi madrasah in Depok, West Java. I visited him several times during my fieldwork in 2013. One day, during a visit, he showed me some parts of his mosque which needed renovation. He estimated that the cost for the necessary renovations was about IDR 5 million (US\$450). He then contacted his students and other Salafi members via BBM (Blackberry Messenger). There were about a thousand contacts in his phone, including me. In his message, he set out the details for which he needed the money, as well as the materials he needed to purchase in order to complete the renovations, including the prices of those materials. At the end of the message, he prayed to God for the donation they would give and he expressed his hope that God would give them a big reward for their donation in the Hereafter. He ended his message with salam (a shortened from assalamu'alaykum - peace be upon you), his account number and his name. Not long thereafter, his BB beeped and several messages came in. They began their replies with Insh $\vec{a}$ Alläh (God willing) and pledged to give a certain amount of money for the renovations.

After some months I visited him again. From a distance I saw that he was standing close to the construction site, talking to someone who was in fact the person who had conducted the renovations. The renovations were close to being finished. I suspected that a big donor was responsible for this renovation, but I was wrong.

The renovations were made possible by donations from the members of the pengajian minggu [weekly gathering] in which I teach. They gave an amount of sadaqah [donation] based on how much money they could spare. Some gave five hundred [thousand], others three hundred, and others one hundred. Some offered their labour instead of money, and women gave food to the workers. We have trained so long about this [donation]. People seem to compete for it. (Interview with Uthman Soleh, Depok, July, 25, 2013).

The swift mobilisation of the funds, as I found in Uthman Soleh's case, was very interesting. How could this be explained? Based on Uthman's information, I discovered that the majority of the donors were ordinary Muslims from a variety of professions ranging from small traders to blue-collar labourers. Some were professionals, such as engineers and businessmen, who may have given larger donations than others. The underlying attitude, however, was that they co-operated 
in a very systematic way. Usman Soleh told me that each member had saved a portion of their income to fund their regular activities, such as religious gatherings and for emergency situations. The renovation of the mosque was considered an emergency as it upset their activities, including their weekly gatherings. According to Uthman Soleh, there were always two or three extra donation events each year, and Salafi members seem to be prepared for these events.

Salafis usually abstain from celebrating Islamic holidays. They do not celebrate Maulid Nabi (the birth of the Prophet Muhammad), or Isra Miraj (The Night Journey and the Ascension), the two major religious ceremonies traditionalist Muslims celebrate. The costs of these rituals are relatively high and may exhaust the financial resources of traditionalist Muslim groups. Almost every mosque and madrasah celebrates Maulid and Isra Miraj during the months of Rabī' al-Awwal and Rajab. A musallá in the neighborhood where I live always celebrates these events. The committees usually go around the village with an estimate of costs (around IDR 5 million (US\$ 450)) and they expect villagers to donate. The village mosque always celebrates these festivals in an even more sophisticated manner, making the costs much higher, those being between IDR 10 and 15 million (US\$950 and US\$1400). Most of the costs are spent on guest speakers, food and drinks, and various competitions (Qur'anic recitation or memorisation) held for children.

The average cost of rituals in Ciputat (in US\$) in 2013

\begin{tabular}{|l|c|}
\hline Isra Mi’raj & 1000 \\
\hline Maulid Nabi & 1000 \\
\hline Tahlïl & 500 \\
\hline Circumcision & 1200 \\
\hline Marriage & 2000 \\
\hline Baby Shower & 500 \\
\hline Hajj Departure & 1000 \\
\hline
\end{tabular}

Traditionalists highly value death rituals, especially tahlìl, which is a must. A family who just lost a family member would even lend money to hold this ritual rather than lose face. Failing to hold the ritual would raise public concern that the relevant family does not know how to respect their deceased. It is believed that holding this ritual is considered the very last good deed members of a family can do for their 
deceased parents or relatives. Many people perform tahlìl for seven nights, starting from the first until the seventh night. For some reason, some perform tablil only for three nights. On odd nights, the rituals are larger than on even nights, and more attendants will come while food and drinks are served. On the last night, processions are even larger, signifying the end of the ritual. The costs of holding a tablìlvary greatly, but a modest tablìl in Ciputat costs around IDR 5 million (US\$500). Many people would, moreover, continue this ritual on the fortieth, hundredth, and thousandth day, with varying scales and budgets.

\section{Conclusion}

The issue of bid'ah reemerges in Indonesian religious discourse due to the Salafi groups, which use it as a weapon to expand their power over other religious believers. This issue reminds the traditionalist Muslims of the bitter past when they were accused of practising nonIslamic rituals. The traditionalists resist Salafis by accusing them of being Wahhabis, the literalist sect that often adopts policies that are harsh against women and the public. Salafis emphasise the importance of orthodox rituals and refrain from practising public rituals associated with traditionalist Muslims. As a result, Salafis preserve their financial resources, which can be used for improving organisational capacities. This politicisation takes place in many different ways. As strategic institutions, mosques have become the target of several Muslim groups to expand their influence.

The patterns of social reproduction within traditionalist Muslim groups are made in and around public rituals. Rituals and social reproduction are integrated into one and serve as powerful discursive knowledge. Financial and human resources are mobilised to perform rituals through which traditionalists maintain their identities and exert power over other Muslim groups. These patterns also allow traditionalists to reach a level piety by performing standard and nonstandard rituals. Based on my observations, many traditionalist villagers claim that performing tablì and haul for their diseased relatives is of great benefit, and helps them become pious Muslims. Furthermore, as part of this social reproduction, traditionalists actively engage in shaping public discourses that contribute to their civic culture. Rituals thus become a medium that produces trust, networking, and political participation. The emphasis of traditionalist Muslim groups 
on performing public rituals, however, also has serious consequences. Because of their extensive and expensive rituals, traditionalists do not have enough money, so to speak, to renovate and rebuild their madrasa and mosques. It is generally believed that those who belong to traditionalist Muslim groups are less organised than Salafis and even less organised than modernists. 


\section{Endnotes}

1. The designation 'traditionalist Muslims' as opposed to 'modernist Muslims', refers to a number of Muslim groups who embrace one of the four Sunni madhhab and, many of them, practice mysticism, sometimes in association with tarekat, Sufi fraternities. In Indonesia, the term refers to the followers of Islamic organizations such as the NU (The Awakening of the Ulama), PERTI (Islamic Education Union), Al-Washliyah, and NW (The Awakening of the Nation). On the modernist groups, see e.g. Noer (1973). On the traditionalist groups, see, e.g. Dhofier (1999).

2. Tahlil is a ritual to commemorate the dead. It is commonly held from the first until the seventh night. It consists of several prayers, in particular the repetition of the words $\bar{l} \bar{a}$ iläha illalläh (there is no God but Allah), from which the world tahlïl originates, reading the Qur'an, and uttering the saläwah (praises for the Prophet Muhammad). Tablil is a public ritual and people in the neighborhood are invited to the house of the berieved. Light meals and snacks are served after the ritual has finished.

3. Many traditionalists perform ziarah kubur as a part of doing good deeds. They not only regularly visit the graves of their ancestors, but also those of saints. Traditionalist Muslims visit the graves of their ancestors at least once a year, usually at the end of the fasting month.

4. See (Jaga Madrasah, Masjid NU, Jangan Sampai Lepas! 2014).

5. This percentage is smaller than that for the growth of the number of churches $(130$ $\%$ ), which has risen from 18,977 to 43,909 at the same period. MORA has made this information available to denounce Christian groups who complain about the bureaucratic barriers they face in erecting new churches, as happens in some regions. See (DMI: Pertumbuhan Masjid Kalah dari Gereja 2014).

6. My survey in 2013 indicates that the Salafi groups have so far 150 schools across the country. Most of them are located in Central Java and Yogyakarta. Others are spread in Sumatra, Kalimantan, and Sulawesi.

7. See (Ketua PBNU: Waspadai Gerakan Wahabi 2011).

8. Talasiman are amulets in unreadable script written by charlatans to invite jinn (spirits).

9. Tamimah are amulets that use Qur'anic verses. Salafis consider tamimah as shirk as it causes believers to deviate from the purity of the faith.

10. Surveys PPIM 2000-5 indicate that $t a h l i l$ has a positive correlation with civic engagement. The participants of tablil tend to have intra-personal trust, social engagement, and tolerance towards other groups.

11. Qunīt is an additional prayer read in the second cycle of the Morning Prayer. It is highly venerated among traditionalists. They read this prayer by raising their hands and saying 'Amin' along with the prayer.

12. Some surveys conducted by the PPIM found that tahlil and ziarah kubur are the most important variables among traditionalist. More than 50 percent of them perform these rituals, while modernists are least likely to perform them.

13. In relation to the prayer, the Salafis use Bin Bāz's Kayfíyat șalāt al-Nabī (The Procedures of the Prayer of the Prophet Muhammad).

\section{Bibliography}

Abdullah, Taufik. 1971. Schools and Politics: The Kaum Muda Movement in West Sumatra (1927-1933). Ithaca: Cornell University Press.

Anwar, M. Syafi'i. 2009. "Political Islam in Post-Soeharto Indonesia: The Contest between 
'Radical-Conservative Islam' and 'Progressive Islam Liberal."' In Southeast Asia and the Middle East: Islam, Movement, and The Longue Durée, Stanford: Stanford University Press, 3349-85.

Azra, Azyumardi. 2004. The Origins of Islamic Reformism in Southeast Asia: Networks of Malay-Indonesian and Middle Eastern 'Ulamā in the Seventeenth and Eighteenth Centuries. Crows' Nest, NSW: Allen \& Unwin; Honolulu: University of Hawai'i Press.

2005. Islam in Southeast Asia: Tolerance and Radicalism. Melbourne: Centre for the Study of Contemporary Islam, Faculty of Law, University of Melbourne.

Bowen, John Richard. 1993. Muslims through Discourse: Religion and Ritual in Gayo Society. Princeton: Princeton University Press.

Burhani, Ahmad Najib. 2013. "When Muslims Are Not Muslims. The Ahmadiya Community and the Discourse on Heresy in Indonesia.” Ph.D. Dissertation. University of Santa Barbara.

Burhanudin, Jajat, and Dina Afrianty, eds. 2013. Mencetak Muslim Modern: Peta Pendidikan Islam Indonesia. Jakarta: Rajawali Pers \& PPIM UIN Jakarta.

Dhofier, Zamakhsyari. 1999. The Pesantren Tradition: The Role of the Kyai in the Maintenance of Traditional Islam in Java. Arizona: Program for Southeast Asian Studies.

Dijk, Kees van. 2013. "Comparing Different Streams of Islam: Wrestling with Words and Definitions." In Islam in Indonesia: Contrasting Images and Interpretations, Amsterdam: Amsterdam University Press.

"DMI: Pertumbuhan Masjid Kalah Dari Gereja." 2014. Republika Online. http:// www.republika.co.id/berita/dunia-islam/islam-nusantara/14/09/30/ncpq39-dmipertumbuhan-masjid-kalah-dari-gereja (November 5, 2014).

Federspiel, Howard M. 1970. Persatuan Islam; Islamic Reform in Twentieth Century Indonesia. Ithaca: Cornell University Press.

Gaffney, Patrick D. 1987. "Authorities and the Mosque in Upper Egypt: Islamic Preacher as Image and Actor." In Islam and The Political Economy of Meaning: Comparative Studies of Muslim Discourse, Berkeley: University of California Press, 192-225.

Geertz, Clifford. 1976. The Religion of Java. Chicago: University of Chicago Press.

Gladney, Dru C. 1998. Ethnic Identity in China, the Making of a Muslim Minority Nationality. Fort Worth: Harcourt Brace College Publishers.

Hasan, Noorhaidi. 2006. Laskar Jihad: Islam, Militancy, and the Quest for Identity in PostNew Order Indonesia. Ithaca: Cornell University.

2008. "Saudi Expansion, the Salafi Campaign and Arabised Islam in Indonesia." In Kingdom without Borders: Saudi Political, Religious and Media Frontiers, New York: Columbia University Press, 263-81.

Haykel, Bernard. 2009. "On the Nature of Salafi Thought and Action." In Global Salafism: Islam's New Religious Movement, New York: Columbia University Press.

Hefner, Robert W. 1985. Hindu Javanese: Tengger Tradition and Islam. Princeton, NJ: Princeton University Press.

— 2000. Civil Islam: Muslims and Democratization in Indonesia. Princeton, NJ: 
Princeton University Press.

“Jaga Madrasah, Masjid NU, Jangan Sampai Lepas!” 2014. NU Online. http://www.nu.or. $\mathrm{id} /$ post/read/56203/jaga-madrasah-masjid-nu-jangan-sampai-lepas (August 25, 2014).

Jaiz, Hartono Ahmad. 2002. Ada Pemurtadan di IAIN. Jakarta: Pustaka al-Kautsar.

Jamhari, and Jajang Jahroni. 2004. Gerakan Salafi Radikal di Indonesia. Jakarta: RajaGrafindo Persada.

"Ketua PBNU: Waspadai Gerakan Wahabi." 2011. Republika Online. http://republika. co.id/berita/nasional/umum/11/12/03/lvmhu5-ketua-pbnu-waspadai-gerakanwahabi (August 18, 2012).

Mahasin, Aswab. 1999. "The Santri Middle Class: An Insider's View." In The Politics of Middle Class Indonesia, eds. Richard Tanter and Kenneth Young. Clayton, Victoria: Monash University Center of Southeast Asian Studies, 138-44.

Majmū'āt Fatāwá Bin Bāz. Vol. 3.

Al-Makassary, Ridwan, and Ahmad Gaus AF. 2010. Benih-Benih Islam Radikal di Masjid: Studi Kasus Jakarta dan Solo. Jakarta: Center for the Study of Religion and Culture.

Muhaimin, A.G. 1995. The Islamic Tradition of Cirebon: Ibadah and Adat among Javenese Muslim. Canberra: ANU E-Press.

Mujani, Saiful. 2003. "Democratic Culture and Muslim Political Participation in Post Suharto Indonesia.” Ph.D. Dissertation. The Ohio State University.

Noer, Deliar. 1973. The Modernist Muslim Movement in Indonesia, 1900-1942. Singapore: Oxford University Press.

Peacock, James L. 1978. Muslim Puritans: Reformist Psychology in Southeast Asian Islam. Berkeley: University of California Press.

PPIM UIN Jakarta. 2004. Barometer Indonesia untuk Demokrasi.

Qodir, Zuly. 2010. Muhammadiyah Studies: Reorientasi Gerakan dan Pemikiran Memasuki Abad Kedua. Yogyakarta: Kanisius.

Rahmat, M. Imdadun. 2005. Arus Baru Islam Radikal: Transmisi Revivalisme Islam Timur Tengah ke Indonesia. Jakarta: Erlangga.

Al-Rasheed, Madawi. 2008. Kingdom without Borders: Saudi Political, Religious and Media Expansion. London, UK: Hurst and Co.

Reid, Anthony. 1993. Southeast Asia in the Age of Commerce 1450-1680, Expansion and Crisis. London and New Haven: Yale University Press.

Ricklefs, M.C. 2006. Mystic Synthesis in Java: A History of Islamization from the Fourteenth to the Early Nineteenth Centuries. Norwalk: EastBridge.

Sabirin. 2009. "Pemberdayaan Masyarakat Pasca Tsunami Berbasis Meunasah." Thesis. Universitas Gadjah Mada. 
Saleh, Fauzan. 2001. Modern Trends in Islamic Theological Discourse in 20th Century Indonesia: A Critical Study. Leiden: Brill.

Trimingham, J. Spencer. 1971. The Sufi Orders in Islam. Oxford: Clarendon Press. al-Wahhāb, Muhammad ibn 'Abd. Kitab Al-Tawhid.

Wahid, Din. 2014. "Nurturing the Salafi Manhaj: A Study of Salafi Pesantrens in Contemporary Indonesia.” Ph.D. Dissertation. Utrecht Universiteit.

Wai-Weng, Hew. 2014. "Cosmopolitan Islam and Inclusive Chinneseness." In Religious Pluralism: State and Society in Asia, eds. Chiara Formichi and Carool Kersten. London: Routledge.

Woodward, Mark R. 1989. Islam in Java: Normative Piety and Mysticism in the Sultanate of Yogyakarta. Tucson: University of Arizona Press.

- 2011. Java, Indonesia and Islam. Temple: Springer Netherlands.

Zamhari, Arif. 2010. Rituals of Islamic Spirituality: A Study of Majlis Dhikr Groups in East Java. Canberra: ANU E Press.

Jajang Jahroni, Faculty of Adab and Humanities, Syarif Hidayatullah State Islamic University (UIN) of Jakarta, Indonesia. Email: jajang. jahroni@uinjkt.ac.id. 


\section{Guidelines}

\section{Submission of Articles}

tudia Islamika, published three times a year since 1994, is a bilingual (English and Arabic), peer-reviewed journal, and specializes in Indonesian Islamic studies in particular and Southeast Asian Islamic studies in general. The aim is to provide readers with a better understanding of Indonesia and Southeast Asia's Muslim history and present developments through the publication of articles, research reports, and book reviews.

The journal invites scholars and experts working in all disciplines in the humanities and social sciences pertaining to Islam or Muslim societies. Articles should be original, research-based, unpublished and not under review for possible publication in other journals. All submitted papers are subject to review of the editors, editorial board, and blind reviewers. Submissions that violate our guidelines on formatting or length will be rejected without review.

Articles should be written in American English between approximately 10.000-15.000 words including text, all tables and figures, notes, references, and appendices intended for publication. All submission must include 150 words abstract and 5 keywords. Quotations, passages, and words in local or foreign languages should 
be translated into English. Studia Islamika accepts only electronic submissions. All manuscripts should be sent in Ms. Word to: http:// journal.uinjkt.ac.id/index.php/studia-islamika.

All notes must appear in the text as citations. A citation usually requires only the last name of the author(s), year of publication, and (sometimes) page numbers. For example: (Hefner 2009a, 45; Geertz 1966, 114). Explanatory footnotes may be included but should not be used for simple citations. All works cited must appear in the reference list at the end of the article. In matter of bibliographical style, Studia Islamika follows the American Political Science Association (APSA) manual style, such as below:

1. Hefner, Robert. 2009a. "Introduction: The Political Cultures of Islamic Education in Southeast Asia," in Making Modern Muslims: The Politics of Islamic Education in Southeast Asia, ed. Robert Hefner, Honolulu: University of Hawai'i Press.

2. Booth, Anne. 1988. "Living Standards and the Distribution of Income in Colonial Indonesia: A Review of the Evidence." Journal of Southeast Asian Studies 19(2): 310-34.

3. Feener, Michael R., and Mark E. Cammack, eds. 2007. Islamic Law in Contemporary Indonesia: Ideas and Institutions. Cambridge: Islamic Legal Studies Program.

4. Wahid, Din. 2014. Nurturing Salafi Manhaj: A Study of Salafi Pesantrens in Contemporary Indonesia. PhD dissertation. Utrecht University.

5. Utriza, Ayang. 2008. "Mencari Model Kerukunan Antaragama." Kompas. March 19: 59.

6. Ms. Undhang-Undhang Banten, L.Or.5598, Leiden University.

7. Interview with K.H. Sahal Mahfudz, Kajen, Pati, June $11^{\text {th }}$, 2007.

Arabic romanization should be written as follows:

Letters: ', $b, t, t h, j, h, k h, d, d h, r, z, s, s h, s, d, t, z, ', g h, f, q, l$, $m, n, h, w, y$. Short vowels: $a, i, u$. long vowels: $\overline{\mathrm{a}}, \overline{\mathrm{i}}, \overline{\mathrm{u}}$. Diphthongs: $a w$, ay. Tà marbūtāa: t. Article: al-. For detail information on Arabic Romanization, please refer the transliteration system of the Library of Congress (LC) Guidelines. 
ستوديا إسلاميكا (ISSN 0215-0492; E-ISSN: 2355-6145) بحلة علمية دولية محكمة تصدر عن مركز دراسات الإسلام والمجتمع (PPIM) بجامعة شريف هداية الله الإسلامية الحكومية بجاكرتا، تعنى بدراسة الإسلام في إندونيسيا خاصة وفي جنوب شرقي آسيا عامة. وتستهدف المجلة نشر البحوث العلمية الأصيلة والقضايا المعاصرة حول الموضوع، كما ترحب بإسهامات الباحثين أصحاب التخصصات ذات الصلة. وتخضع جميع الأبحاث المقدمة للمجلة للتحكيم من قبل لجنة مختصة. تم اعتماد ستوديا إسلاميكا من قبل وزارة التعليم و الثقافة بجمهورية إندونيسيا باعتبارها دورية علمية (قرار المدير العام للتعليم العالي رقم: 56/DIKTI/Kep/2012).

ستوديا إسلاميكا عضو في CrossRef (الإحالات الثابتة في الأدبيات الأكاديمية) منذ ع ا • ب، و بالتالي سإن جميع المقالات التي نشرها مرقمة حسب معرّف الوثيقة الرقمية (DOI) .

$$
\begin{aligned}
& \text { قيمة الاشتر الك السنوي خارج إندونيسيا: }
\end{aligned}
$$

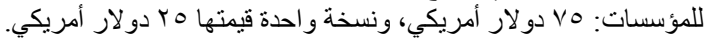

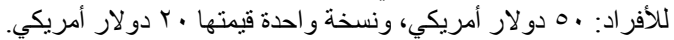

$$
\begin{aligned}
& \text { والقيمة لا تشمل نفقة الإرسال بالبريد الجوي، ونسي. }
\end{aligned}
$$

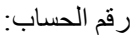

$$
\begin{aligned}
& \text { خارج إندونيسيا (دولار أمريكي): }
\end{aligned}
$$

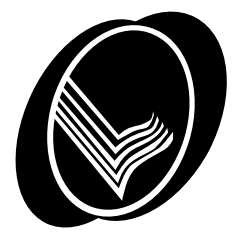




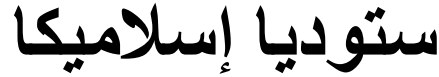 \\ مجلة إندونيسيا للار اسات الإسلامية}

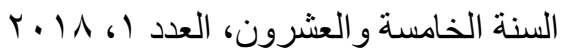

$$
\begin{aligned}
& \text { أزيو ماردي أزرا } \\
& \text { مدير التحرير: } \\
& \text { هيئة التحرير: } \\
& \text { سيف المزاني } \\
& \text { جمهاري } \\
& \text { ديدين شفر الدين }
\end{aligned}
$$

محمد قريش شهاب (جامعة شريف هداية الله الإسلامية الحكومية بجاكرتا)

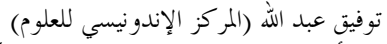

نور أ. فاضل لو بيس (الجامعة الإسلامية الحكومية سومطرة الشمالية الشمالية) م. ش. ريكليف (جامعة أستر اليا الحكومية كانبيرا)

مارتين فان برو نيسين (جامعة أتريخة)

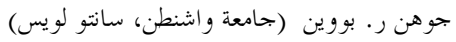

محمد كمال حسن (الجامعة الإسلامية العالمية - ماليزيا)

فر كنيا م. هو كير (جامعة أستراليا الحكومية كانبيرا)

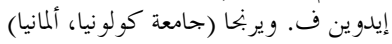

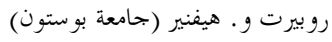

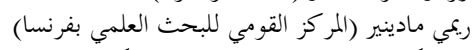

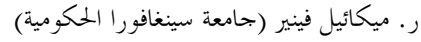

ميكائيل ف. لفان (جامعة فرينشتون)

مساعد هيئة التحرير:

مراجعة اللغة الإنجليزية:

بنيمن ج. فريمان

دانيل فتريون

موسى بتول

مراجعة اللغة العربية:

أحمدي عثمان المبلة

تصميم الغلاف:

س. س برنكا 



\section{لالتوايا السالمسيا}




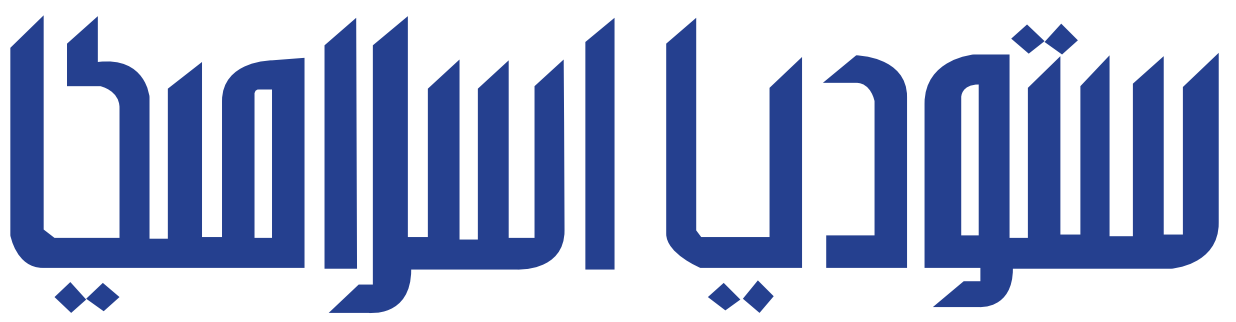

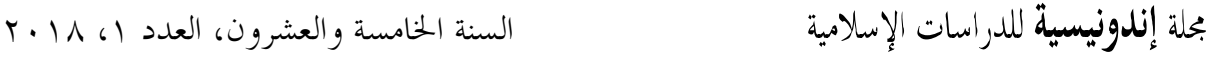

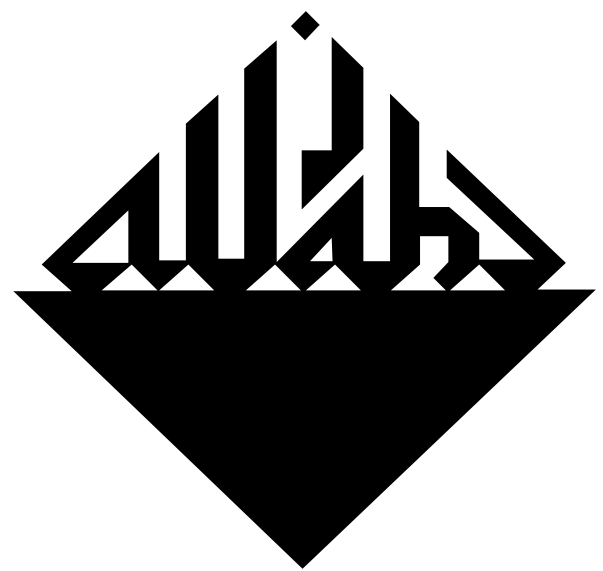

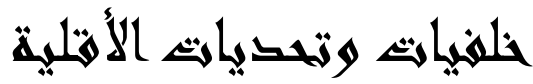

Pontianak المسلمة الصبيمية هيمى هرمانشاه 